\begin{tabular}{l} 
JOURNAL OF APPLIED SMART ELECTRICAL \\
NETWORK AND SYSTEMS (JASENS) \\
Vol. 2 No. 1 (2021) $08-14 \quad$ ISSN Media Elektronik: 2723-5467 \\
\hline
\end{tabular}

\title{
Telemonitoring Perkecambahan Benih Jati Emas Dengan Induksi Medan Magnet Statis
}

\author{
Mila Kusumawardani ${ }^{1}$, Zulfa Anggraini Kusumaningtyas ${ }^{2}$, Farida Arinie ${ }^{3}$, Ridho Hendra Yoga Perdana ${ }^{4}$ \\ 1,2,3,4 Jurusan Teknik Elektro, Politeknik Negeri Malang, Malang, Indonesia \\ ${ }^{1}$ mila.kusumawardani@polinema.ac.id, ${ }^{2}$ zulfajhupa@gmail.com, ${ }^{3}$ farida.arinie@ polinema.ac.id, \\ ${ }^{4}$ mail.rhyp@gmail.com*
}

\begin{abstract}
In the cultivation of teak plants often have problems because teak seeds have a thick and hard skin or impermiabel (difficult to penetrate) to water and gas so as to slow germination. The magnetic field can increase the growth rate in inactive seed seeds because the magnetic field affects the physical and chemical properties of water as a germination medium. Water exposed by the magnetic field can be absorbed easily with tissues in the seeds, thus shortening seed dormancy and increasing the percentage of seed germination. This study aims to understand the growth process of dormancy seed germination, To know the influence of magnetic fields on the growth of teak seed seeds, as a solution to the problem of seed dormancy in teak seed seeds. Therefore, the method used in this study is to provide exposure to teak seeds and make tools for monitoring teak growth in real time with the parameters of planting media moisture (to see the absorption of water) and high seeds (for the growth of teak seeds), so that used YL69 sensor for soil moisture and sharp infrared sensor gp2y0a02yk0f for high plants.
\end{abstract}

Keywords: Teak, dormancy, magnetic field, telemonitoring, YL69

\begin{abstract}
Abstrak
Dalam pembudidayaan tanaman jati sering mengalami kendala karena biji jati memiliki kulit yang tebal dan keras atau bersifat impermiabel (sulit ditembus) terhadap air dan gas sehingga dapat memperlambat perkecambahan. Medan magnet dapat meningkatkan laju pertumbuhan pada benih biji tidak aktif karena medan magnet memperngaruhi sifat fisika maupun kimia air sebagai medium perkecambahan. Air yang dipapar oleh medan magnet dapat diserap dengan mudah dengan jaringan pada biji, sehingga dapat mempersingkat dormansi biji dan meningkatkan prosentasi dari germinasi biji. Penelitian ini memiliki tujuan Untuk memahami proses pertumbuhan perkecambahan benih dormansi, Untuk mengetahui pengaruh medan magnet terhadap pertumbuhan benih biji pohon jati, Sebagai penyelesaian masalah dormansi biji pada benih biji pohon jati. Oleh karena itu metode yang digunakan pada penelitian ini yaitu memberikan pemaparan pada biji jati dan membuat alat untuk monitoring pertumbuhan jati secara realtime dengan parameter kelembaban media tanam (untuk melihat daya serap air) dan tinggi benih (untuk pertumbuhan biji jati), sehingga digunakan sensor YL69 untuk kelembaban tanah dan sensor infrared Sharp gp2y0a02yk0f untuk tinggi tanaman.
\end{abstract}

Kata kunci: Jati, dormansi, medan magnet, telemonitoring, YL69

Diterima Redaksi : 24-05-2021 | Selesai Revisi : 21-06-2021 | Diterbitkan Online : 30-06-2021

\section{Pendahuluan}

Pohon jati adalah tanaman yang termasuk dari jenis tropika dan subtropics yang dikenal dengan kualitasnya. Pohon jati memiliki manfaat yaitu batang pohon (kayu jati) dapat digunakan sebagai furniture dari perabotan rumah, dll. Banyaknya permintaan konsumen akan kayu jati membuat kayu tersebut banyak dieksploitasi oleh oknum yang memanfaatkan hal ini, apabila tidak diiringi dengan pembudidayaan maka kayu jati akan menjadi langka. Budidaya tanaman jati sering ditemukan kendala yaitu salah satunya adalah biji yang lambat dalam melakukan germinasi yang dikarenakan biji dari tanaman pohon jati ini memiliki kulit yang tebal dan keras yang memiliki sidat impermiabel (sulit ditembus) terhadap air dan gas sehingga dapat menghambat pertumbuhan. Semakin keras biji dan kurangnya faktor yang menunjang pertumbuhan, maka waktu yang diperlukan untuk germinasi perkecambahan semakin lama [1].

Germinasi adalah suatu proses pertumbuhan embrio serta komponen biji yang dapat tumbuh dengan normal dan dapat menjadi tahap tumbuhan yang baru [2]. Dormasi dapat diartikan ketidak mampuan dari sebuah benih untuk melakukan perkecambahan pada lingkungan yang optimum yang dapat disebabkan oleh keadaan fisik dari kulit benih, keadaan fisiologis dari 
embrio atau kombinasi keduanya keadaan tersebut. wireless yang ada pada node akan diterima oleh modul Namun dormansi bukan berarti benih tersebut mati atau wireless yang lainnya yang ada pada local server. Local tidak dapat tumbuh kembali, karena dormansi pada server bertugas untuk menampilkan dan menata data benih dapat dipatahkan dengan menggunakan skarifikasi yang telah didapat. Hasil monitoring akan ditampikan secara mekanik maupun kimiawi [1]. Benih dikatakan pada halaman WEB berbentuk tabel informasi dari dorman apabila benih tersebut sebenarnya hidup tetapi masing - masing parameternya dan beberapa informasi tidak berkecambah walaupun diletakkan pada keadaan lainnya.

yang secara umum telah memenuhi persyaratan bagi perkecambahan. Perkecambahan (germinasi) tidak akan terjadi selama benih tersebut belum melalui masa dormansinya, atau sebelum benih tersebut dikenakan suatu perlakuan khusus. Dormansi juga dapat dikatakan sebagai suatu fase dimana kulit biji dalam kondisi yang keras menghalangi penyerapan [3].

Medan magnet dapat meningkatkan laju pertumbuhan pada benih biji tidak aktif karena medan magnet memperngaruhi sifat fisika maupun kimia air sebagai medium perkecambahan. Air yang dipapar oleh medan magnet dapat diserap dengan mudah dengan jaringan pada biji, sehingga dapat mempersingkat dormansi biji dan meningkatkan prosentasi dari germinasi biji [4].

Pada artikel ini kami melakukan pendekatan menggunakan teknologi IoT pada benih biji jati, sehingga dapat membantu proses dormansinya. Dengan melakukan paparan medan magnet statis agar dapat dipaparkan kepada benih biji kadaluarsa tanaman jati emas dan memonitoring pertumbuhan biji dengan memperhatikan beberpa parameternya.

\section{Metode Penelitian}

\subsection{Blok Diagram}

Pada Gambar 1 di jelaskan tentang diagaram blok pada sistem penelitian yang dilakukan. Pertama memberi perlakuan pada biji yaitu dengan cara pemilahan, perendaman, dan sortir biji. Setelah itu akan dilakukan pemaparan atau induksi oleh medan magnet terhadap biji yang telah siap. Apabila telah dilakukan dilakukan penyemaian biji (penanaman biji pada media tanam). Jika biji sudah ditanam maka dilakukan monitoring pertumbuhan selama beberapa hari parameter monitoring meliputi kelembaban dan tinggi batang yang akan tumbuh. Data yang didapat dari sensor akah diolah pada mikrokontroler dan akan diupload oleh modul wireless untuk disampaikan ke local server dan data akan ditata dan ditampilkan pada web yang berupa table informasi dan beberapa informasi tambahan.

Pada gambar 2 blok diagram menjelaskan bibit akan dimonitoring pertumbuhan (tinggi) tanaman dan juga memonitoring kelembaban dari tanaman tersebut. system monitoring menggunakan lokal server dengan beberapa node yang akan mengirimkan hasil monitoring. Kedua sensor akan diolah datanya menggunakan mikrokontroler yaitu Arduino dan data akan diupload menggunakan wireless yaitu NRF24L01 dengan menggunakan jaringan hospot atau tathering dari handphone. Sinyal yang dipancarkan dari modul
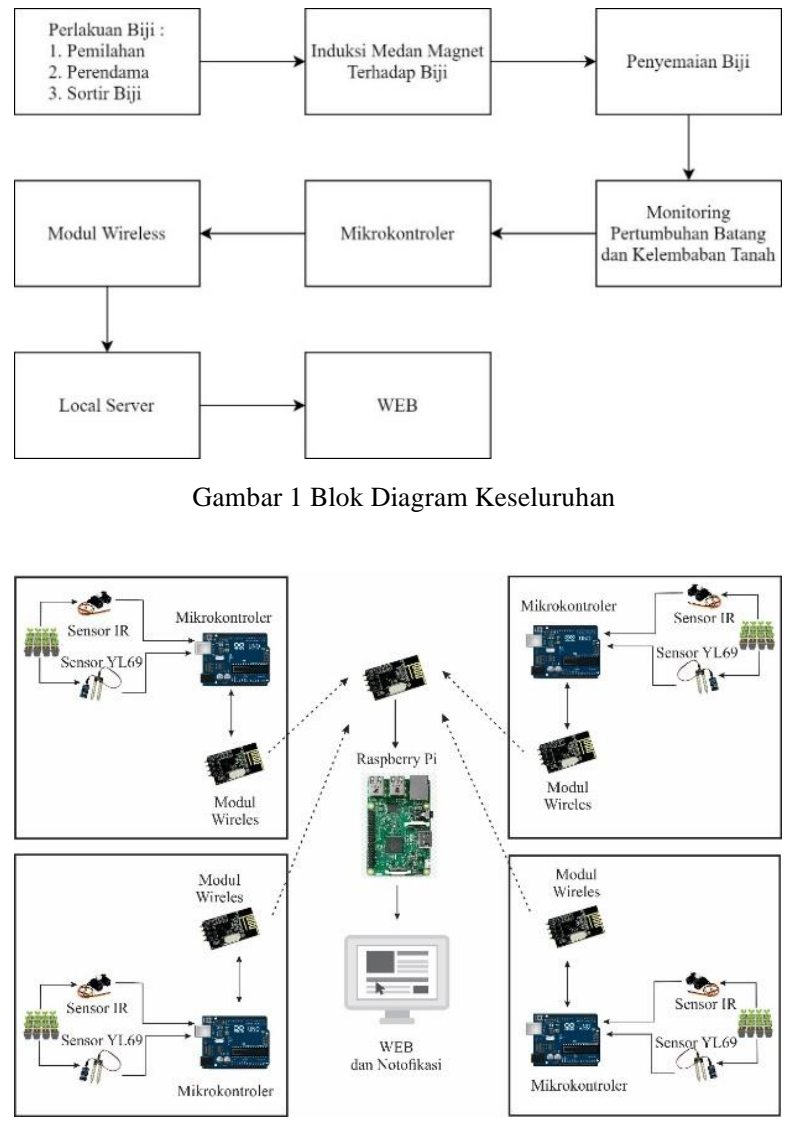

Gambar 2 Blok Diagaram Sistem Monitoring

\subsection{Flowchart Sistem}

Pertama hal yang dilakukan adalah melakukan pemilahan biji dengan menggunakan biji yang tidak rusak dan melakukan penimbangan awal sebelum biji direndam. Langkah kedua adalah melakukan perendaman, perendaman pun dilakukan selama 2 hari dengan menggunakan air bersih (air sumur bukan air PDAM). Langkah ketiga adalah mengeluarkan biji yang tidak mengapung dan tidak lunak apabila biji terendam makan biji dapat dulakukan Langkah berikutnya. Untuk proses sortir biji dilakukan penimbangaan untuk melihat kalua biji lebih berat setelah direndam daripada sebelum direndam.

Pengaturan kuat medan dilakukan dengan cara melakukan pengukuran terhadap magnet yang sudah jadi untuk mengetahui berapa kuat medan yang digunakan dalam pemaparan biji. Siapkan juga pewaktu untuk memberi Batasan waktu pemaparan pada biji. Selanjutnya dilakukan pemaparan medan magnet pada biji dengan pengulangan sebanyak 2 kali dengan 
beberapa perbedaan waktu pemberian paparan medan Mikrokontroler yang digunakan adalah Arduino uno dan magnet.

Algoritma 1: Cara kerja menginduksi medan magnet Input: biji jati

1: pemilihan jenis jati

2: perendaman biji jati ( 2 hari)

3: if biji jati sudah lunak dan mengapung

4: $\quad$ Kembali ke 1

5: sortir biji untuk induksi medan magnet

6: atur kuat medan dan waktu

7: induksi biji jati dengan medan magnet

8: if biji jati mulai visibilitas benih

9: $\quad$ biji siap disemai

10: Kembali ke 7

Setelah dilakukan pemaparan makan biji dilihat apakah terjadi viabilitas pada biji tersebut, apabila terjadi viabilitas maka biji akan siap untuk penyemaian atau penanaman biji pada media tanam.

Pada algoritma 1 diterangkan bahwa awal penanaman biji pada media tanam lalu akan dimonitoring pertumbuhan tanaman dengan menggunakan sensor IR dan selanjutnya akan dimonitoring kelembaban dengan menggunakan sensor YL69. Setelah itu data akan di kumpulkan dan diolah oleh mikrokontroler. Lalu data akan dikirim pada lokal server dengan menggunakan raspberry pi sebagai lokal server untuk mengurutkan data dan nantinya data akan ditampilkan pada tampilan web yang menunjukkan nilai kelembaban media tanam dan nilai pertumbuhan dari benih tanaman.

\subsection{Perencanaan Rangkaian Sistem}

Rangkaian node sensor terdiri dari mikrokontroler yang digunakan untuk mengolah data yang didapat oleh beberapa sensor yang terhubung dengan mikrokontroler dan sensor pada masing - masing polybag adalah sensor IR dan sensor soil moisturize. Node sensor terdiri dari masing - masing polybag yang digunakan untuk pembibitan. Jadi 1 node untuk 1 polybag.

\section{Algoritma 2: sistem monitoring}

Input: biji jati, kecepatan tumbuh tinggi batang, kelembaban media tanam

1: penyemaian biji pada media tanam

2: upload data kelembaban media tanam dan kecepatan tumbuh tinggi batang

3: if berhasil di upload

4: tampilkan data di web

5: Kembali ke 2

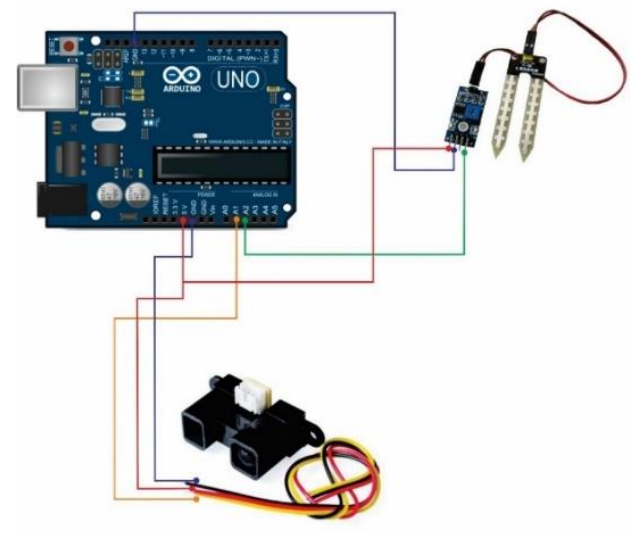

Gambar 4 Rangkaian Sensor pada masing - masing Polybag

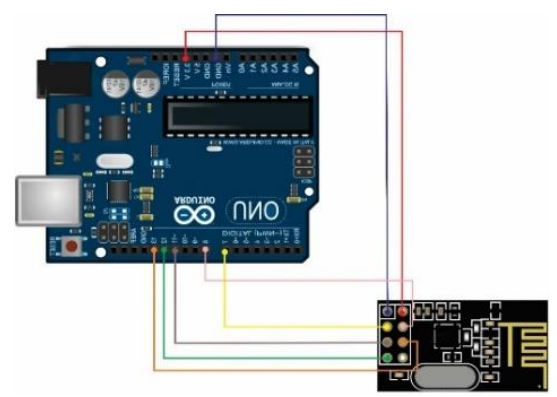

Gambar 5 Rangkaian Wireless Masing - Masing Polybag

\section{Hasil dan Pembahasan}

Pada gambar 8 merupakan rangkaian pada masing masing polybag untuk memonitoring pertumbuhan bibit

Pada gambar 3 merupakan gambar rangkaian antara jati, sedangkan untuk gambar 9 adalah rangkaian untuk raspberry pi dengan modul wireless. Rangkaian ini lokal server.

digunakan sebagai lokal server dari komunikasi pengiriman data yang digunakan.

Rangkaian node sensor terdiri dari mikrokontroler yang digunakan untuk mengolah data yang didapat oleh beberapa sensor yang terhubung dengan mikrokontroler.

Journal of Applied Smart Electrical Network and Systems (JASENS) 


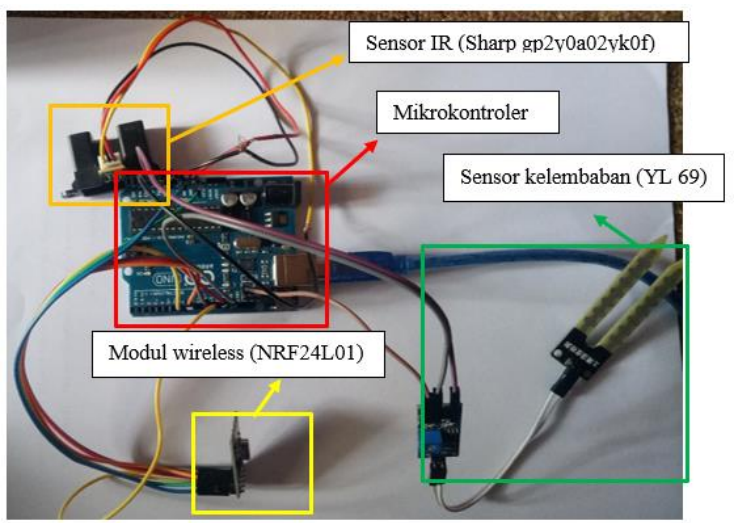

Gambar 6 Rangkaian Pada Masing - Masing Polybag

Untuk sensor kelembaban ditancapkan pada masing masing media tanam, sedangkan untuk sensor IR digantungkan pada kawat yang memiliki tinggi $30 \mathrm{~cm}$ yang dihitung dari permukaan tanah hingga sensor yang nantinya kawat itu akan ditancapkan pada media tanam sehingga sensor dapat mengambil data dengan menghitung selisih jarak antara sensor dengan benih yang mulai muncul pada permukaan tanah, sehingga dapat mengetahui tinggi benih tersebut.

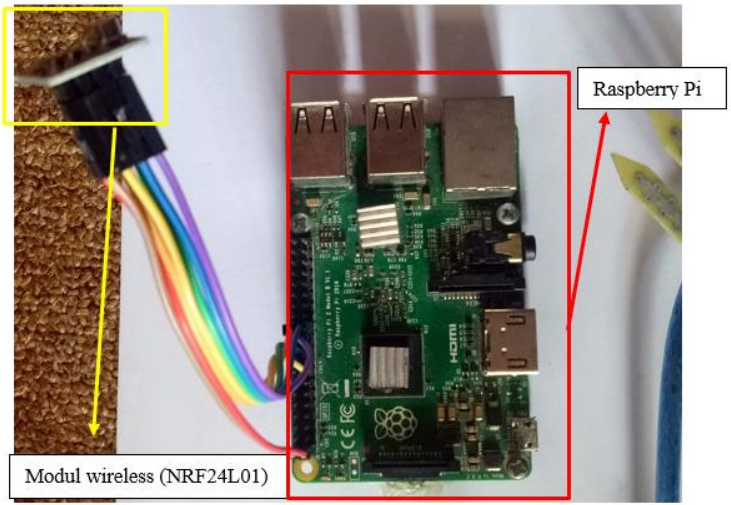

Gambar 7 Rangkaian Untuk Server

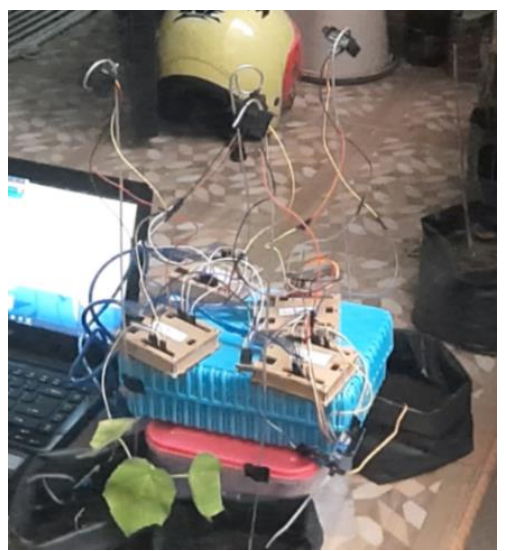

Gambar 8 Rangkaian Pada Jati Putih

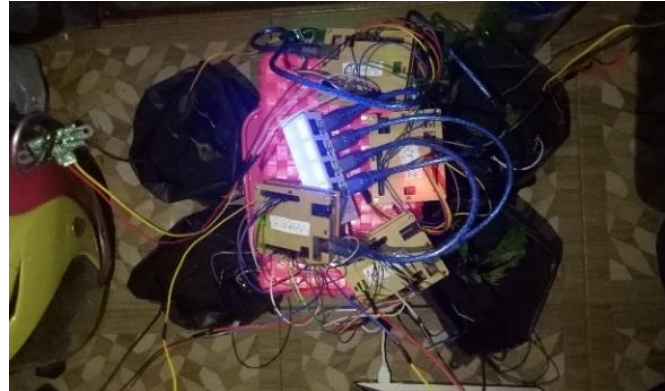

Gambar 9 Rangkaian Pada Jati Emas

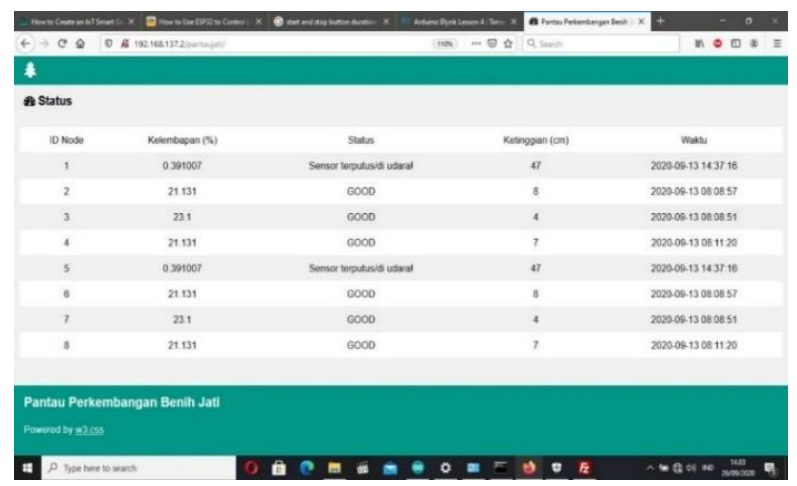

Gambar 3 Tampilan WEB

Gambar diatas merupakan contoh tampilan web yang digunakan untuk memonitoring biji jati. Dalam tabel 1 terdapat hasil pengukuran dari 8 node yang ada pada masing - masing polybag.

Tabel 1 Fungsionalitas WEB

Desain WEB
Tampilan WEB

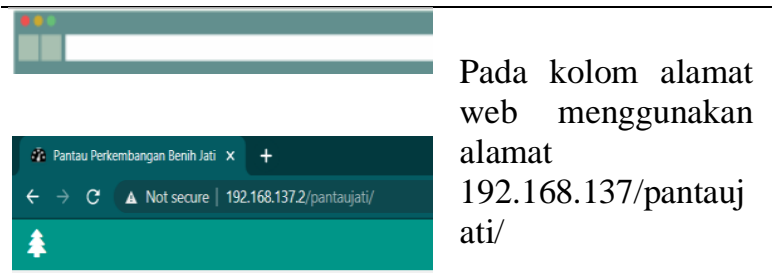

Pada bagian bawah terdapat judul web untuk desain "TELEMONITORI NG

Pantau Perkembangan Benih Jati

BIBIT JATI" dan pada WEB adalah

"Pantau

Perkembangan

Benih Jati”. 


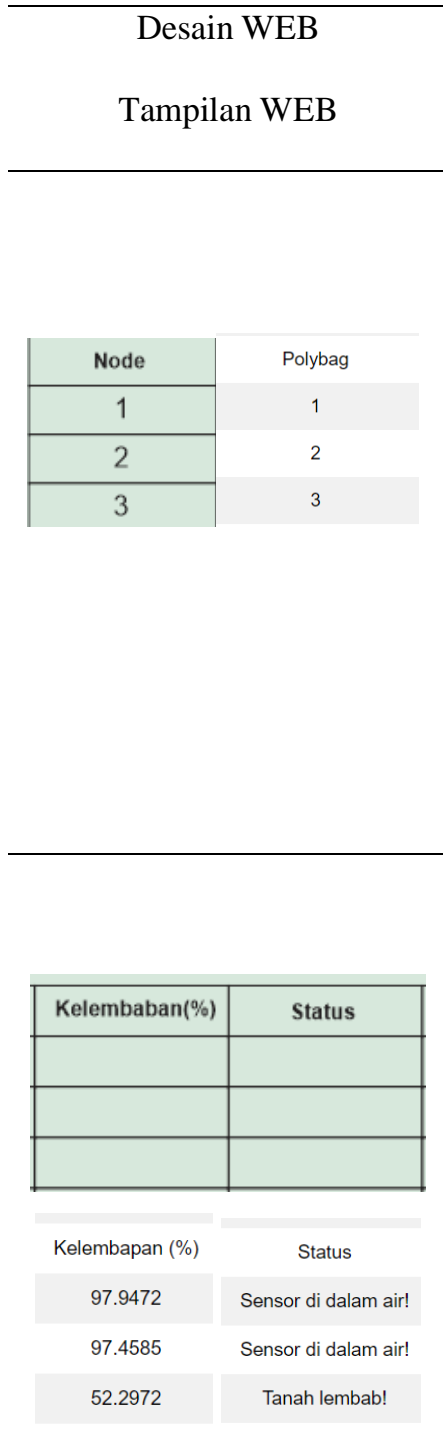

Untuk kolom
pertama adalah
kolom node pada
desain desain web
node
memberitahukan Id
node yang digunakan
sedangkan pada web
untuk

mempermudah

menggunakan

polybag sehingga

untuk polybag 1

memiliki Id node 1

begitu pula

seterusnya.

Untuk kolom

berikutnya terdapat

kolom kelembaban

berurutan dengan

status kelembaban

tanah oleh sensor

kelembaban. Untuk

kelembaban berisi presentase dari nilai kelembaban yang telah tersensor. Untuk status adalah keterangan seberapa lembab tanah tersebut seperti yang telah dijabarkan pada script program sebelumnya.

\begin{tabular}{|c|c|}
\hline \multirow[t]{3}{*}{ Ketinggian (cm) } & Ketinggian $(\mathrm{cm})$ \\
\hline & 23 \\
\hline & 23 \\
\hline & 33 \\
\hline
\end{tabular}

Kolom selanjutnya adalah kolom untuk melihat nilai dari ketinggian benih tanaman dengan satuan $\mathrm{cm}$.

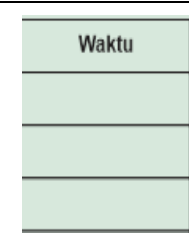

Waktu 2020-10-11 13:07:07 2020-10-11 13:08:41 2020-10-11 13:17:08

Kolom terakhir adalah kolom waktu yang menjelaskan waktu pengiriman data pada WEB

Status pada tabel dibedakan menjadi 5 jenis staus. Berikut penjabaran script dari status keterangan kelembaban pada web :

if soilRead is $\theta$ :

soilstatus = 'Sensor hubung singkat!'

elif soilRead $>=0$ and soilRead < 370 :

soilstatus = 'Sensor di dalam air!'

soilRead $=\operatorname{remap}($ soilRead, $0,1023,100$,

0 )

elif soilRead >= 370 and soilRead < 600:

soilstatus = 'Tanah lembab!'

soilRead $=$ remap $($ soilRead $, 0,1023,100$,

$0)$

elif soilRead $>=600$ and soilRead < 1000:

soilstatus = 'Tanah kering!'

soilRead $=$ remap $($ soilRead $, 0,1023,100$, 0 )

elif soilRead >= 1000 and soilRead < 1024: soilstatus = 'Sensor terputus/di udara!' soilRead $=\operatorname{remap}($ soilRead $, 0,1023,100$, $0)$

Pada script diatas menunjukkan bahwa hasil keterangan dipengaruhi oleh nilai dari sensor. Nilai yang dibaca oleh mikrokontroler menjelaskan adanya persamaan nilai apabila terbaca 0 maka nilai kelembaban nya adalah 100\% sedangkan apabila nilai terbaca 1024 maka nilai kelembabannya adalah $0 \%$.

Tabel 2 Presentase Perkecambahan

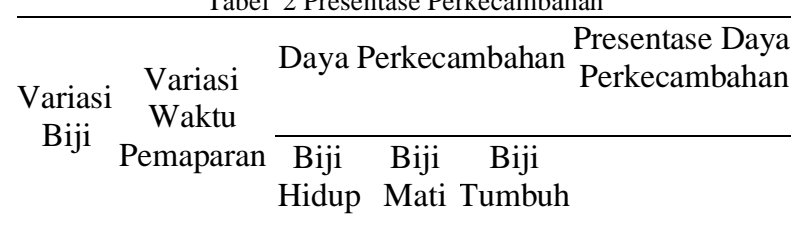

\begin{tabular}{cccccc}
\hline \multirow{2}{*}{$\begin{array}{c}\text { Biji } \\
\text { Jati }\end{array}$} & 20 menit & 6 & 4 & 1 & $16.66 \%$ \\
\cline { 2 - 5 } Emas & 30 menit & 6 & 4 & 1 & $16.66 \%$ \\
\cline { 2 - 6 } & 40 menit & 5 & 5 & 2 & $40 \%$ \\
\hline \multirow{2}{*}{$\begin{array}{c}\text { Biji } \\
\text { Jati } \\
\text { Putih }\end{array}$} & 20 menit & 9 & 1 & 2 & $22.22 \%$ \\
\cline { 2 - 5 } & 30 menit & 8 & 2 & 1 & $12.5 \%$ \\
& 40 menit & 9 & 1 & 2 & $22.22 \%$
\end{tabular}

Tabel 2 ini berdasarkan biji setelah dilakukan perendaman dan biji setelah dilakukan pemaparan. Biji hidup adalah biji yang tenggelam saat dilakukan perendaman biji. Sedangkan biji mati merupakan biji yang mengapung pada saat perendaman, biji tumbuh adalah biji yang dapat tumbuh setelah penanaman 21 hari.

Setelah biji dilakukan perendaman dapat dilihan biji hidup dan biji mati apabila biji mati maka sudah tidak terdapat embrio di dalam biji tersebum oleh karena itu biji tidak bisa sampai kedasar karena sudah kosong sehingga mengapung.

Analisa dari perkecambahan pertama kita harus mencari daya perkecambah. Dengan rumus daya perkecambah sebagai berikut:

Journal of Applied Smart Electrical Network and Systems (JASENS) 


$$
D=\frac{A}{B} \times 100 \%
$$

Keterangan:

D: Daya Kecambah

A: jumlah benih yang berkecambah

B: jumlah benih yang dikecambahkan

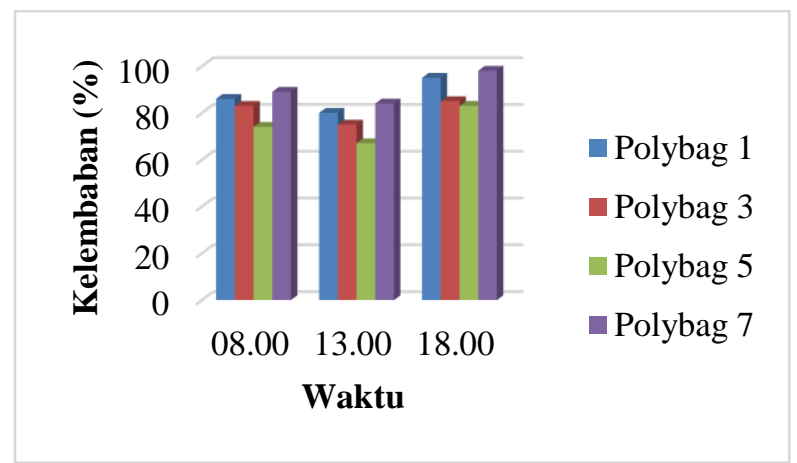

Gambar 11 hasil uji kelembaban biji jati emas hari ke -7

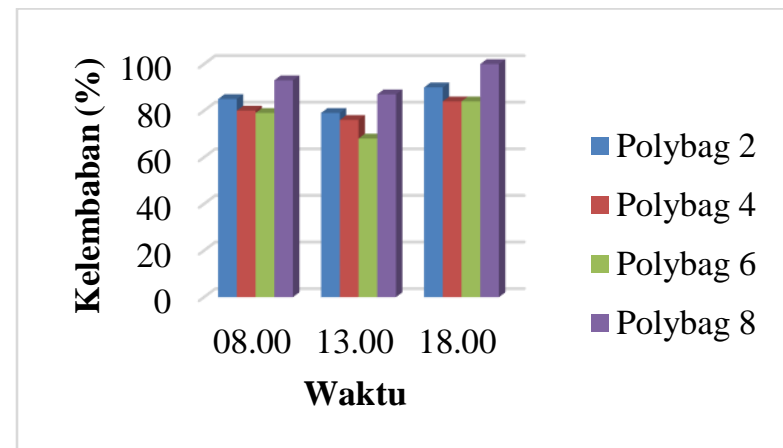

Gambar 12. Hasil Pengujian Kelembaban Biji Jati Emas Hari Ke - 7

Pada gambar 11 dan 12 merupakan pengujian kelembaban setelah penanaman biji yang ditunjukan kelembaban media tanam dari perkecambahan biji jati emas dan jati putih. Untuk jati emas pada hari ke -7. Pada masa tanam ini dilihat dari 4 polybag yang berisi jati emas dapat dilihat pada polybag 5 dengan lama pemaparan medan magnet 40 menit dengan 2 kali pengulangan dalam sehari yaitu memiliki proses penyerapan air yang tinggi sehingga memiliki nilai kelembaban yang lebih kecil daripada yang lainnya. Sedangkan untuk biji yang tidak dipapar oleh medan magnet yaitu pada diletakkan pada polybag ke 7 yang memiliki paling tinggi diantara 3 polybag yang lainnya dengan tinggi kelembaban yaitu sekitar $90 \%$. Sedangkan untuk jati putih terlihat jika pada polybag 6 dengan lama pemaparan medan magnet 40 menit dengan 2 kali pengulangan dalam sehari memiliki proses penyerapan air yang tinggi sehingga memiliki nilai kelembaban yang lebih kecil daripada yang lainnya yaitu dengan nilai sekitar 70\%, kecuali pada jam 18.00 karena sebelumnya dilakukan penyiraman pada tanaman. Pada polybag 8 adalah perkecambahan tanpa control (tidak dipapar medan magnet) maka nilai kelembaban nya sekitar $90 \%$ dengan memiliki tingkat kelembaban yang paling tinggi daripada lainnya.

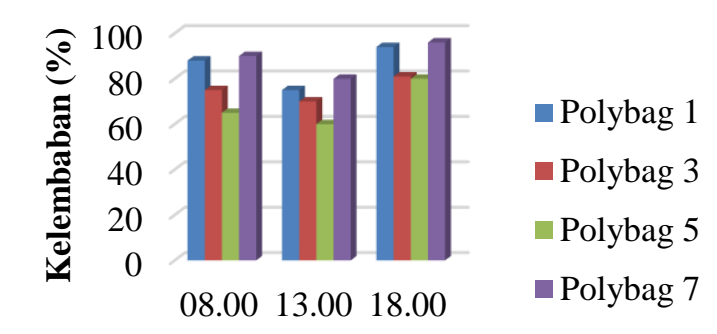

$$
\begin{aligned}
& \text { Waktu }
\end{aligned}
$$

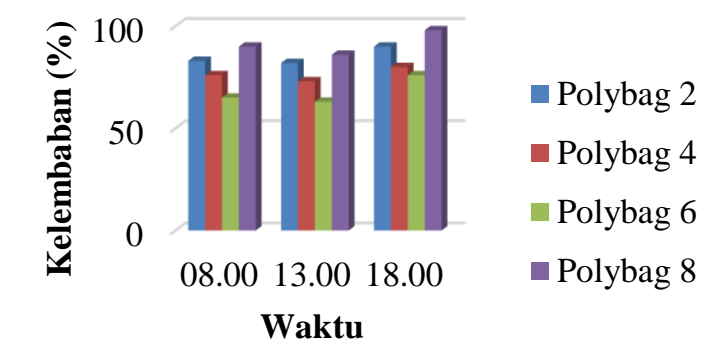

Pada gambar 13 dan 14 ditunjukan kelembaban media tanam dari tanaman jati emas dan jati emas. Untuk jati emas pada hari ke -21. Dapat dilihat pada grafik jika pada node 7 tetap memiliki kelembaban yang tinggi dari hari - kehari. Sedangkan dua node 3 dan 5 memiliki nilai kelembaban yang hamper sama dari waktu ke waktu yaitu nilai kelembaban yang kecil. Terutama pada saat siang hari. Untuk jati putih ditunjukan kelembaban media tanam dari tanaman jati putih pada hari ke -21 . Sama dengan biji jati emas grafik polybag 2 dan 8 memiliki kelembaban yang tinggi dengan nilai range sekitar $80 \%$ - 9\%.

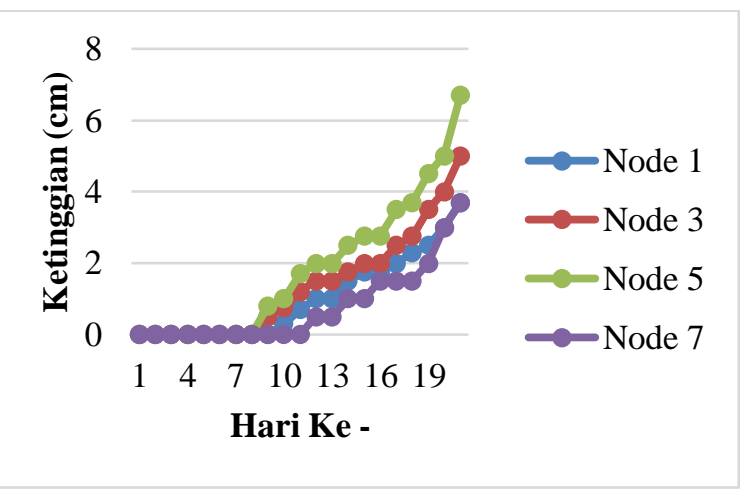

Gambar 15 Pengujian Pertumbuhan Biji Jati Emas

Gambar 15 dan 16 merupakan hasil dari monitoring pertumbuhan biji jati emas dan jati putih. Pada grafik 
dapat dilihat untuk jati emas pada hari ke 9 kualitas benih pengujian, medan magnet memberikan pengaruh jati tumbuh dengan memberikan data tinggi benih terhadap penyerapan air pada media tanam dari biji jati kurang dari $1 \mathrm{~cm}$ karena biji masih baru muncul pada yaitu untuk yang dipapar oleh medan magnet memiliki permukaan tanah pada polybag 3 dan 5 yang merupakan range 60\% - 80\% sedangkan untuk yang tidak dipapar biji dengan pemberian control (dipapar medan magnet) medan magnet memiliki range nilai yang lebih ringgi untuk polybag 3 dengan waktu pemaparan 30 menit dan yaitu $80 \%$ - 100\% yang dapat menyebabkan biji polybag 5 dengan waktu pemaparan 40 menit yang membusuk. Serta pemberian pemaparan medan magnet masing - masing pemaparan dilakukan pengulangan memberikan perbedaan dari laju pertumbuhan biji jati pemaparan 2 kali dalam sehari pemaparan. Pada polybag yaitu untuk polybag yang diberi paparan medan magnet 3 dan 5 memiliki nilai tinggi perkecambahan dengan rata dapat tumbuh terlebih dahulu pada hari ke 9 sudah - rata 0,5 cm pada hari ke 9. Pada hari ke 9 biji pada terlihat pada permukaan tanah dengan tinggi kurang dari polybag 3 dan 5 memiliki pertumbuhan yang awal $1 \mathrm{~cm}$, sedangkan untuk biji yang tidak diberi perlakuan daripada biji pada polybag lainnya. Untuk jati putih pada pertumbuhannya sedikit lambat yaitu pada hari ke 12 hari ke 9 biji mulai tumbuh pada polybag 4 dan 6 dengan baru terlihat pada permukaan. Selain itu hasil rata - rata tinggi benih yaitu $0,85 \mathrm{~cm}$. sedangkan pada pengamatan dari media tanam berupa kelembaban yaitu hari ke 10 benih pada polybag 2 mulai tumbuh, biji ini kelembaban dengan lama paparan 40 menit memiliki dberi kontrol (dipapar medan magnet) dengan lama kelembaban yang paling kecil dengan range $\pm 60 \%-$ pemaparan 20 menit dan mengalami pengulangan $85 \%$ sedangkan untuk biji jati yang tidak dipapar medan sebanyak 2 kali dalam sehari. Untuk polybag 8 benih magnet memiliki kelembaban yang tinggi yaitu $\pm 85 \%$ baru tumbuh terlihat pada permukaan tanah pada hari ke $100 \%$. Untuk pertumbuhan dengan lama paparan 30 12 dengan tinggi benih 0,5 . Benih pada polybag 8 menit dan 40 menit memulai pertumbuhan terlebih merupakan benih yang tidak diberi kontrol (tidak dahulu sedangkan untuk biji yang tidak dipapar memiliki dipapar medan magnet).

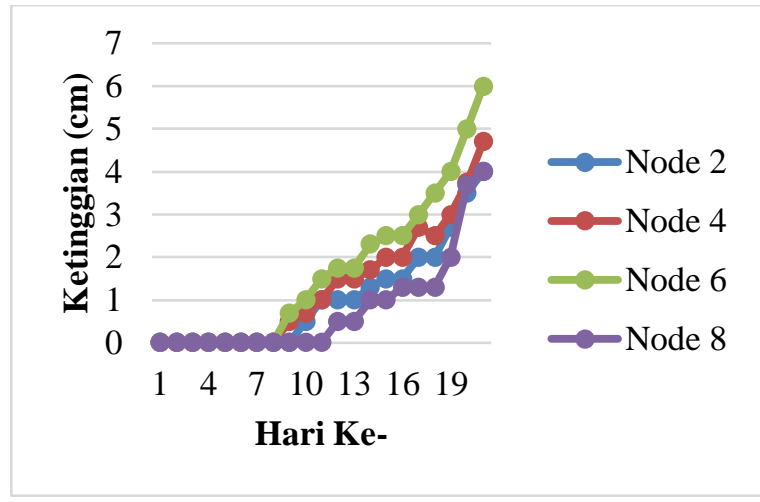

Gambar 16 Pengujian Pertumbuhan Biji Jati Emas

\section{Kesimpulan}

Pada penelitian ini dilakukan pengujian biji pohon jati terhadap medan magnet. Berdasarkan hasil pertumbuhan biji yang terlambat.

\section{Daftar Rujukan}

[1] Saputri, 2017, Pengaruh Pemaparan Medan Magnet Terhadap Masa Dormansi Pada Biji Jati (Tectona Grandis L.), Sarjana, Lampung, Universitas Islam Negeri Raden Intan Lampung.

[2] Imelda Agustina Zuhria R., 2014, Pengaruh Pemberian Variasi Medan Listrik Terhadap Perubahan Pola Dormansi Serta Germinasi Pada Benih Padi, Brawijaya Physics Student Journal, Vol. 2, no. 1 .

[3] C.D, R. A., 2013, Efek Medan Listrik Dc Terhadap Dormansi Dan Germinasi Benih Semangka(Citrullus Lanatus )', Skripsi.

[4] Budiman, A. et al. (2016) 'Karakterisasi Struktur Kristal dan Sifat Magnetik Magnet Stronsium Ferit Pasir Besi Batang Sukam Kabupaten Sijunjung Sumatera Barat'.

[5] Prasetio, F. A. A. (2016) 'Pengaruh Penambahan Air Rebusan Kentang (Solanum Tuberosum L.), Bap Dan Naa Terhadap Induksi Tunas Jati Emas (Cordia Subcordata) Secara In Vitro', Skripsi.

[6] Sari, Y. (2018) 'Pengaruh Lama Paparan Medan Magnet 0.2 Mt Terhadap Pertumbuhan Vegetatif Tomat (Lycopersicum Esculentum Mill.) Dari Benih Lama Dan Baru', Skripsi. 